CUSTODIANS OF THE INTERNET 
This page intentionally left blank 


\section{CUSTODIANS OF THE INTERNET}

platforms, content moderation, and the hidden decisions that shape social media

tarleton gillespie 
Copyright ( $\odot 2018$ by Tarleton Gillespie.

All rights reserved.

Subject to the exception immediately following, this book may not be reproduced, in whole or in part, including illustrations, in any form (beyond that copying permitted by Sections 107 and 108 of the U.S. Copyright Law and except by reviewers for the public press), without written permission from the publishers. The Author has made this work available under the Creative Commons Attribution-Noncommercial-ShareAlike 4.0 International Public License (CC BY-NC-SA 4.0) (see https://creativecommons.org/licenses/ by-nc-sa/4.0/)

An online version of this work available; it can be accessed through the author's website at http://www.custodiansoftheinternet.org.

Yale University Press books may be purchased in quantity for educational, business, or promotional use. For information, please e-mail sales.press@yale. edu (U.S. office) or sales@yaleup.co.uk (U.K. office).

Set in Minion type by IDS Infotech Ltd., Chandigarh, India. Printed in the United States of America. Library of Congress Control Number: 2017953111 ISBN 978-0-300-17313-0 (hardcover: alk. paper) A catalogue record for this book is available from the British Library. This paper meets the requirements of ANSI/NISO Z39.48-1992 (Permanence of Paper) 